\title{
PROGRESS IN ADVANCED HIGH TEMPERATURE MATERIALS TECHNOLOGY
}

John C. Freche and G. Mervin Ault

NASA-Lewis Research Center, Cleveland, Ohio

AB STRACT

The need for advanced materials capability has never been as great as at this time in our nation's history. Energy shortages demand more efficient operation of existing equipment of al1 types as well as new and imaginative methods of power conversion. Advanced materials are the key to achieving improved performance via higher cycle operating temperatures, lighter structural components, and adequate resistance to the various environmental factors associated with such equipment. Significant progress has recently been made in many high temperature material categories pertinent to such applications by the industrial community, DOD and NASA. These include metal matrix composites, superalloys, directionally solidified eutectics, coatings, and ceramics. Each of these material categories is reviewed and the current state-of-the-art identified, including some assessment, when appropriate, of progress, problems, and future directions. 


\section{Introduction}

Historically, the major advances in high temperature materials of high strength with resistance to oxidation and corrosion has resulted from efforts to meet the insatiable demand for higher temperatures in critical components of aircraft engines for military and commercial applications. The turbine technology evolved for aircraft has spun off (Fig. 1) to other transportation modes such as ships, and experimentally in trains, trucks, and busses as well as to important non-transportation uses such as drives for gas line pumping stations and, especially, the generation of electric power. For central station power, combined cycle systems using advanced gas turbines in conjunction with a steam plant, are considered to be one of the most viable options for base load service in terms of overall efficiency and busbar energy cost $(1,2,3)$. As a consequence, it is vital that continued advances be made in turbine technology if significant performance and economic gains are to be realized in major industrial sectors of our economy. Materials improvements in intermediate and high temperature materials are the key to achieving such advances.

Consideration of the various turbine components indicates the kind of improvements that are required and the specific benefits that san result (Fig. 2). Thus, by increasing the strength of intermediate temperature materials that are used for turbine disks, increased rotor speeds and fewer turbine stages can be achieved with resultant reductions in turbine engine weight and cost. Similarly, increases in allowable turbine blade and stator vane temperatures will permit operation at higher cycle temperatures or with reduced cooling air. The resultant benefits are incrcased power output, decreased fue 1 consumption, and/or decreased maintenance cost.

An important new emphasis for high temperature materials technology results from the requirement for petroleum conservation and the increasing cost of petroleum products. Turbine engines typically use a clean kerosene-type fuel. But the costs of such fuels has increased by a factor of 3 in the past three years. For many applications, it is desired to use cheaper cuts from petroleum or even residuals. In the future, it is desired to use liquid fuels derived from coal and, if possible, gaseous fuels derived from coal burned in fluidized beds. All of these fuels are characterized by containing many impurities that can lead.to severe erosion and corrosion of current materials. The tolerance limits for current materials and coatings need to be defined. To tolerate dirty fuels will probably necessitate greatly improved coatings for turbine vane and blade materials or operation at lower material temperatures.

It must be emphasized that extremely high costs are involved in bringing a new material from the laboratory stage to engine usage. For example, it has been estimated by one engine manufacturer that approximately $\$ 15$ million are required to bring a DS eutectic system to the point where it can be incorporated as a turbine blade in an aircraft engine. Thus, it becomes of paramount importance that the most advantageous cholces be made in selecting the engine component and material to be addressed. To do this requires that careful benefit-cost analyses be made. Several NASA-sponsored benefitcost studies $(4,5,6,7)$ quantify the gains that can be achieved by increasing material capability for aircraft gas turbines. An example of the economic benefits of material improvements for specific engine components for a fleet of 500 subsonic commercial transport aircraft with a 3000 nautical mile range, and a load factor of $55 \%$ of the total passenger capacity of 180 is provided by the benefit-cost studies $(6,7)$. The benefits (including return on investment and direct operating cost) over the life of the aircraft assuming the following advanced materials could be employed, would be $\$ 45$ million for prealloyed powder metallurgy disks, $\$ 90$ milion for directionally solidified eutectic blades, and $\$ 200$ million for ceramic vanes.

In this paper, the authors review the state-of-the-art of materials technology and assess future material developments utilizing critical turbine components as a framework for discussion. 
Materials for Intermediate Temperature Applications - Disks

Prealloyed powder processing $(8,9,10)$ holds promise for providing superalloys with increased strength for turbine disk applications. Although current PM disk alloy development is principally concerned with existing alloys such as Rene' 95 (11) and IN-100 (12), work is underway with more advanced alloys which show significant improvements in strength (Fig. 3). Even further strength increases are anticipated over the next decade. For example, for powder metallurgy processing, alloys can be specifically designed to accommodate larger quantities of strengtheners without encountering the segregation which would cccur if they were cast. In this way, the feature of greater structural homogeneity resulting from the prealloyed powder process can most effectively be utilized.

Fig. 3 shows the $650^{\circ} \mathrm{C}\left(1200^{\circ} \mathrm{F}\right)$ yield strengths of promising candidate PM disk alloys such as AF 115 (13), IIB-7 (1.4), and AF2-1DA (15). These can be processed to have $650^{\circ} \mathrm{C}$ (12000F) yield strergths in excess of $1380 \mathrm{MN} / \mathrm{m}^{2}$ (200 ks i). Since in some advanced turbine designs consideration is being given to still higher maximum disk temperatures, it is interesting to see how the $6500 \mathrm{C}(12000 \mathrm{~F})$ yield strength is affected when the PM alloys $A F 115$ (16), AF2-1DA (17), and IIB-11MOD (18) are processed to give maximum $760^{\circ} \mathrm{C}\left(1400^{\circ} \mathrm{F}\right)$ strength. Significantly lower $650^{\circ} \mathrm{C}$ (12000F) strengths result. This emphasizes that adequate PM disk alloy strength over a range of temperatures requires that a suitable compromise in a processing heat treatment selection be made.

In addition to improved short time strength compared to conventional forged alloys, improvements in long time creep rupture strength are also required to make PM alloys viable candidates for disks, particularly for high temperature disk applications. Significant improvements have already been obtained (Fig. 4). An important aspect to be noted, however, is that the relatively large grain size needed for high creep rupture strength calls for higher solution treatment temperatures than would be used to achieve the greater short time tensile strength. Since mechanical working effects are then annealed out, this will reduce the tensile strength. Therefore, the development of optimum processing and heat treating steps is a most important key to the developmert: of advanced PM disk a1loys.

Although significant increases in static strength are possible with PM disk alloys, further research is required to insure that advanced prealloyed powderalloys also have cyclic life improvements commensurate with their static strength improvements. It is important that early in the research for new materials-process combinations, realistic disk test cycles be used in evaluating cyclic crack initiation and crack growth behavior. It is unfortunate that we do not have available a simple low cost screening test for this purpose. However, the fluidized bed type of thermal fatigue testing which is being used extensively to rate materials with regard to thermal fatigue testing (19) can be used to provide some measure of the relative resistance to crack initiation and measurement of crack growth rate. But the actual engine cycles cannot be reproduced in such facilities.

Decreased life cycle cost represents the greatest concern in gas turbine disks. Reductions in initial cost can be achieved by prealloyed powder processing. Fig. 5 compares this process schematically with the conventional casting and forging process. It is apparent that less starting material, fewer operational steps, and less machining is required to reach the final disk shape. For a commercial turbine disk, currently produced in large volume by forging and costing $\$ 10,000$ per disk, the savings in both raw material and machining could be $\$ 2,000(20)$. Of the process variations, the greatest cost reduction opportunity exists for the as hot isostatically pressed (HIP) to near net shape approach, with a smaller cost opportunity possible for the extruded or HIP plus warm work approaches. 
Materials for High Temperature Application

Low Stress - Vanes, Combustors, Regenerators

Several key turbine power plant components must withstand very high temperatures, but the stresses to which they are subjected are relatively low. The most promising materials for several of these applications are discussed in the next sections.

ODS alloys.- For use as turbine stator vanes, the oxide dispersion strengthened (ODS) alloys offer a significant improvement over both currently used and the most advanced conventional cast superalloys (Fig. 6). Their metal use temperature ranges up to $1230^{\circ} \mathrm{C}\left(2250^{\circ} \mathrm{F}\right)$ and they should see service as stator vanes within the next five years. Several of the more promising, HDA 8077 (a NiCrAl with $\mathrm{Y}_{2} \mathrm{O}_{3}$ ), MA 754 (a NiCr with $\mathrm{Y}_{2} \mathrm{O}_{3}$ ) and YD-NiCrAl (a $\mathrm{NiCrAl}$ with $\mathrm{Y}_{2} \mathrm{O}_{3}$ ) are shown on the figure.

The melting point of these materials is about $13700^{\circ}$ (25000F). This high melting point and greater microstructural stability of these materials provide additional pluses compared to conventional cast superalloys for vane use. The advantage of greater overtemperature capability may be seen in Fig. 7, in which a conventionally cast MAR M-509 and a TD-NiCr vane are compared 21$)$. These vanes were subjected to over temperature while being tested in the same nozzle assembly of an experimental engine. The cast vanes, although cooled, melted. The uncooled $\mathrm{TD}-\mathrm{NiCr}$ vanes remained essentia11y undamaged. Another advantage of ODS alloys for vane application is their greater thermal fatigue resistance. Some ODS alloys have shown up to 10 times greater resistance to cracking under simulated vane operating conditions than conventionally cast superalloys (21)

Combustors also fall into the category of high temperature, low stress applications where ODS alloys afford significant potential. Combustor components require formable, weldable, as well as oxidation, distortion, and thermal fatigue resistant sheet alloys. For service temperaturcs near $980^{\circ} \mathrm{C}\left(1800^{\circ} \mathrm{F}\right)$ the conventional cast and wrought alloys, Haynes Alloy 188 , Inconel 617 and the developmental MERL 72 show good potential $(22,23)$. However, the ODS NiCrAls have a potential for a $90^{\circ} \mathrm{C}$ (1600F) higher temperature capability than conventional sheet materials. Manufacture of an ODSNiCrAl sheet product has been demonstrated $(24)$ but there are no commercial sources for sheet at present. Once the advantageous role of ODS-NiCrA1 vanes is established, it is expected that attention will be focused on the manufacture of ODS-NiCrAl sheet products.

There are a number of problem areas with ODS materials which must be noted, however. Foremost is the historical one of high alloy cost (about 5 times that of conventional superalloys). Another, the low oxidation resistance of the $\mathrm{NiCr}$ base has largely been solved. As in virtually all instances where there is a pronounced directionality of grain structure, transverse ductility may be a problem. But this can probably be adequately handled by trading off some longitudinal strength for increased transverse ductility by appropriate heat treatments that reduce the grain structure directionality. Another problem is the creep-behavior of oDS sheet alloys for such applications as combustor components. With the increased diffusion rates at the higher temperatures for which these alloys are intended, diffusional type creep could be the major contributor to the creep process. In ODS sheet alloys, such as $\mathrm{TD}-\mathrm{NiCr}$, diffusional creep has been observed and the creep-damage by this process was shown to be severe (25), although there appears to be a threshold stress below which significant diffusional creep does not occur. This factor must be taken inlo consideration in engine component designs where zero creep may be required.

The problem of high cost is being addressed by the development of improved powder manufacturing techniques such as mechanical alloying (26) and current 
activities to scale-up for large production quantities promise substantial reductions in the cost of these materials. Simpler recrystallization techniques can be employed substituting furnace recrystallization for the more time-consuming gradient annealing. Finally, further cost reductions are anticipated by use of near-net-shape fabrication techniques such as are currently under development in a NASA-sponsored program (27). This program includes extension and forging of consolidated preforms to provide a vane gcometry that requires minimal machining to final shape.

The problem of low cyclic oxidation resistance observed in the early TD-NiCr alloys has effectively been eliminated as may be seen from Fig. 8 by changing to a NiCrAl base that includes 4 to 5 weight \% aluminum. The figure shows that essentially no weight loss occurred with the NiCrAls after severe cyclic testing ( $\mathrm{r} . \mathrm{t}$. to $1200^{\circ} \mathrm{C}\left(2200^{\circ} \mathrm{F}\right)$ ) in a Mach 1 burner. Hot corrosion resistance was also significantly improved (28). The NiCrAls form an aluminum containing oxide scale which provides excellent oxidation resistance. For long time service (e.g., at least 3000 hours) however, the ODS NiCrAls will probably require a protective coating as will be discussed later.

Ceramics.- As shown in Fig. 6, ceramics offer the highest use temperature potential of all materials for stator vanes, on the order of $14000 \mathrm{C}$ (26000F).

Currently the most promising ceramics appear to be $\mathrm{Si}_{3} \mathrm{~N}_{4}$ and $\mathrm{SiC}$. Extensive screening studies of some 35 different ceramics in the NASA Lewis Mach 1 burner $(29,30)$ have shown them to have the most favorable thermal shock resistance. Other investigators $(31-34)$ have also shown the superiority of $\mathrm{Si}_{3} \mathrm{~N}_{4}$ and $\mathrm{SiC}$. These ceramics also have excellent high temperature creep rupture properties as may be seen from Fig. 9 . Commercial hot pressed $\mathrm{Si}_{3} \mathrm{~N}_{4}$ (35) has substantially higher use temperature capability (approximately $1320^{\circ} \mathrm{C}\left(2400^{\circ} \mathrm{F}\right)$ at stresses of approximately $50 \mathrm{mN} / \mathrm{m}^{2}(7 \mathrm{ksi})$ which are typical of those encountered in stator vanes, than the strongest known conventionally cast vane alloy, WAZ-16(36). It also shows about a $100^{\circ} \mathrm{C}\left(200^{\circ} \mathrm{F}\right)$ advantage over the ODS alloys.

Both $\mathrm{Si}_{3} \mathrm{~N}_{4}$ and $\mathrm{SiC}$ are ur er development and significant improvements in high temperature strength are being achieved as shown in Fig. 9. Work is underway under NASA sponsorship (37). to improve creep-rupture strength by decreasing the alkali metal content from approximately 2500 to less than $400 \mathrm{ppm}$ and by lowering $\mathrm{O}_{2}$ content to less than $1 \%$. The intent is to limit the amount of strength reducing second phase formation at the grain boundaries which results from the reaction of such impurities with densification additives such as $\mathrm{MgO}$ and $\mathrm{Y}_{2} \mathrm{O}_{3}$. Further strength improvements are possible with these ceramics by improving processing procedures such as powder handling, sintering, and hot pressing. Although no creep rupture data are yet available, another promising $\mathrm{Si}_{3} \mathrm{~N}_{4}$ base material is the class known as SiAlONs. These are solid solutions of $\mathrm{Al}_{2} \mathrm{O}_{3}$ in $\mathrm{Si}_{3} \mathrm{~N}_{4}$. Demonstrated advantages are that the SiAlONs do not require sintering to reach high density (94\%) and that they appear to have outstanding thermal shock resistance $(38)$.

Another extremely advantageous low stress turbine power plant application for ceramics is for the regenerator (essentially a rotary heat exchanger) in automotive gas turbines (Fig. 10). The advantages of using ceramics for such an application are that higher cycle operating temperatures, greater fuel economy and lighter structural weight may be realized. Glass ceramics such as lithium aluminum silicate (LAS) are candidates for gas turbine regenerators, an example of which is shown in Fig. 11. The porous nature of the part which permits air to pass through it is evident from the figure. There is a major problem associated with the use of ceramic regenerators. It is chemical attack by sulfuric acid and sodium, both of which are present in exhaust gas systems. The sulfuric acid occurs as a result of the combustion 
of sulfur-containing diesel fuels, while the sodium can come from the fuel itself, road salt, or from engine operation in a marine environment. Contamination of the LAS regenerator results in an ion-exchange reaction-- $\mathrm{Li}$ ions in the matrix material are replaced by $H$ ions in the sulfuric acid and by $\mathrm{Na}$ ions in the salt or fuel. As a result of these reactions, the thermal coefficient of expansion increases and cracking of the regenerator disk occurs. This problem is being attacked by attempting to develop a MAS material with corrosion resistance superior to LAS and with a thermal expansion coefficient lower than normal MAS (39). Another approach is to modify the basic LAS material for improved corrosion resistance (40).

It should be noted that ceramics for turbine application have become the center of much effort in recent years. For example, there is the ARPA program $(35,36,41,42,43,44)$. The program is intended to demonstrate that ceramics can be applied successfully as stator vanes, turbine blades and disk, crmbustor and nose cone components in a $1370^{\circ} \mathrm{C}$ (25000F) gas temperature automotive turbine power plant. Another phase of this program seeks to demonstrate the effectiveness of ceramic first stage stator vanes for a $1370^{\circ} \mathrm{C}(25000 \mathrm{~F})$ gas temperature 30 megawatt ground power turbine installation. It is expected that the vehicular unit combustors, ducts and stators will meet the 1978 goal of 200 hours of operation at a maximum turbine inlet temperature of $2500^{\circ} \mathrm{F}$. Major effort is going into the most demending application of ceramics, the vehicular turbine rotor.

\section{High Stress - Turbine Blades}

For high stress applications such as turbine blades, substantial increases in use temperature can be expected by means of directiona1 structures of several types (Fig. 12). Initial advances were made with conventional nicke1 base alloys such as PWA $664(45)$ in which grains were aligned parallel to the direction of the major stress axis by means of directional solidification. Further increases can be expected from monocrystals (46). The directionality concept is also being applied to eutectic systems with considerable success. Directionality of structure is also the key to the ODS $+\boldsymbol{\gamma}^{\prime}$ systems and tungsten fiber superalloy composites.

Directiona11y solidified eutectics - Major research and development effort is being expended in industry and government to exploit eutectic systems. Figure 13 provides a comparison of the 1000 hour creep rupture properties $(47,48)$ of the major eutectic systems currently under study and directionally solidified MAR M-200 + Hf. At turbine blade operating conditions, the DS eutectics now afford about a $30-80^{\circ} \mathrm{C}\left(50-150^{\circ} \mathrm{F}\right)$ use temperature advantage, or a 40-60\% increase in creep iupture strength.

Figure 14 shows the microstructure of the two major types of eutectic systems, a typical rod or fiber reinforced system, HAFCO, and a typical lamellar reinforced system $\boldsymbol{\gamma} / \mathbf{\delta}$. The matrix has been etched away to bring into relief the two types of reinforcing phases. In both systems a relatively ductile matrix is reinforced by a brittle phase. Most rod or fiber (not all are perfect rods as may be seen from the figure) reinforced systems utilize some type of carbide fibers (Hf carbide in HAFCO and TaC in both $\mathrm{CoTaC}$ and $\mathrm{NiTaC}$ ) ranging from 5 to 15 volume percent (49). The matrices are generally complex. For example, the matrix of the NiTaC systems consists of a $\boldsymbol{\gamma}^{\prime}$ precipitate within a $\boldsymbol{\gamma}$ nickel solid solution con taining $\mathrm{Cr}$ and $\mathrm{Al}$ to provide oxidation resistance and precipitation strengthening. Additions of $W$ or Mo can be made to provide additional solid solution strengthening. The $\gamma / \gamma^{\prime}-\delta$ alloy $(\mathrm{Ni}-20 \mathrm{Cb}-6 \mathrm{Cr}-2.5 \mathrm{~A} 1$ ) is typical of the lamellar reinforced systems. The $\boldsymbol{\delta}\left(\mathrm{Ni}_{3} \mathrm{Cb}\right)$ lamellae make up approximately 40 volume percent and this contributes to very low transverse ductility at low and intermediate temperatures, as will be discussed subsequently. The matrix consists of a $\boldsymbol{\gamma}^{\prime}$ precipitate within a complex $\boldsymbol{\gamma}$ nickel solid solution. 
A number of problem areas exist which must be solved before eutectic systems can be effectively utilized. Foremost, and common to all systems is the slow growth rate directionally solidified eutectics require in their manufacture, typically less than $3 \mathrm{~cm} / \mathrm{hr}(48,50)$. Work is being directed toward achieving more acceptable rates from a blade fabrication standpoint $(48,51)$.

Another potential problem with some eutectics is that of thermal instability upon thermal cycling. A visual example of this is shown for the CoTaC system in Fig. 15 (52). It may also be seen that by suitable compositional changes such instabilities can be overcome. The thermal instability demonstrated (Figs. 15(a) and (b)) upon cycling 2000 times between 425 and $1100^{\circ} \mathrm{C}$ ( 800 and $2000^{\circ} \mathrm{F}$ ) could have been caused by a number of factors whose individual roles have not as yet been well defined----- thermal coefficient of expansion mismatch between fibers and matrix, fiber solubility in matrix, fiber face energy of formation, and imperfections of reinforcing fiber phase $(49,52,53)$. Figures $15(\mathrm{c})$ and (d) show that by substituting HfC for $T a C$ fibers instability during thermal cycling was totally eliminated $(54)$. A bettex understanding of the importance of the role of the individual factors that can contribute to such thermal instability must be obtained, but it is apparent that the problem is not insurmountable.

A further area of considerable concern with some eutectic systems is that of low transverse ductility at the intermediate temperatures. This poses fatigue problems in the blade. Another problem is design of the blade root because of normally imposed shear and bending stresses. The solution to the latter problem may require modified (lower stress) root designs, perhaps modified bulb root designs rather than the more conventional fir tree roots. Figure 16 shows the transverse tensile fracture strain for representative eutectic systems compared to a currently used directionally solidified superalloy DS MAR M-200. The rod or fiber reinforced systems (NiTaC and CoTaC, $(48,55)$ have reasonably good room and intermediate temperature transverse ductility which compares well with DS MAR M-200 + Hf(50). However, the lamellar $\gamma / \gamma-\delta$ system has relatively low transverse ductility at these temperatures. Attempts are being made to alter the deformation mechanism of the high (40 volume percent) brittle intermetallic phase $\left(\delta, \mathrm{Ni}{ }_{3} \mathrm{Cb}\right.$ ). Recent efforts have improved $7600^{\circ}(14000 \mathrm{~F})$ transverse fracture strain from

0.2 to $0.9 \%$. This wes achieved (50) by obtaining a fully lamellar structure by decreasing growth rate from 3 to $2 \mathrm{~cm} / \mathrm{hr}$ and by the addition of $0.06 \% \mathrm{C}$. Heat treatments $\left(870^{\circ} \mathrm{C}, 1600^{\circ} \mathrm{F}\right)$ also appear to provide some improvement although the mechanism is as yet unknown. Despite the problems cited, however, eutectic systems are promising candidates for high stress turbine applications and it is expected that some eutectic systems will see at least limited engine service as aircraft turbine engine blades within this decade.

ODS + gamma prime alloys. - Recent advances in the production of oxide dispersion strengthened alloys have introduced oDs superalloys as possible contenders for advanced turbine blade application. For this use, the high strength of a gamma prime $\left(\gamma^{\prime}\right)$ strengthened alloy (needed ac the blade root) is combined with the elevated temperature strength derived from dispersion strengthening (needed in the airfoil). At $11000 \mathrm{C}$ (20000F) the creep-rupture life of experimental ODS superalloys such as ODS WAZ-D (56) and the International Nickel Company's "Alloy B"(57) compare favorably with conventionally cast random polycrystalline $\gamma^{\prime}$ strengthened alloys and directionally solidified eutectic alloys. As shown in Fig. 17, these alloys have use Lemperatures of $1150^{\circ} \mathrm{C}\left(2100^{\circ} \mathrm{F}\right)$ and $1115^{\circ} \mathrm{C}$ (2040 $0^{\circ}$ ) respectively, for 1000 hour 1 ife at a stress of $103 \mathrm{MN} / \mathrm{m}^{2}$ (15 ksi). An added advantage of the ODS alloys is their higher incipient melting temperature derived from the compositional uniformity inherent in processing by powder metallurgical techniques. 
The ODS superalloys are relative newcomers to the scene and only sketchy data exist. Thus, their potential for blade application remains largely uncharted except for their outstanding strength. Those tested to date have shown less ductility $(\sim 1 \%$ for WAZ-D) than conventional blade alloys (typically $3 \%$ ). A potential problem area may be low transverse rupture ductility which is expected to be less than the longitudinal ductility. However, it is anticipated that the interest generated by this class of materials will shortly result in a more definitive exaluation of their potential.

Composites.- Of al1 the directional metallic systems, tungsten fiber reinforced auperalloys afford potentially the highest use temperature capability for turbine blades, but their application to service is also furthest down the road (Fig. 12). These materials combine the high temperature strength of $W$ wires with the ductility, toughness, and oxidation resistance of a superalloy matrix. Although the technology for these composites is not as advanced as for the DS eutectics (in-situ composites) considerable research is underway in this area (58 to 63 ). The significant strength advantage of $W$ fiber reinforced superalloys over DS eutectics (up to $2 \% 1 / 2$ times) and current superalloys (up to 5 times) is apparent from Fig. 18 which shows a comparison of their $10900 \mathrm{C}$ (2000\%) 1000-hour density normalized data. The actual composite data (solid lines) were obtained with a uniform reinforcement of 70 volume percent tungsten fibers along the length of the specimens. For an average 30 volume percent reinforcement with varying fiber content along the blade span, calculated results (dotted lines) are shown which take into account potential composite degradation due to fiber matrix interaction over 1000 hours exposure. Because of improvements in compatibility since the data were obtained, some of the calculated results are even more favorable. To make the 30 volume percent of reinforcing fibers a viable concept, the fibers have to be suitably distributed along the blade span to accommodate spanwise variation in blade centrifugal force. A 30 volume percent of reinforcement would result in composite blades of approximately the same weight as those of current superalloy blades. This would be accomplished by taking advantage of the greater stiffness and strength of the composite to reduce blade thickness and taper.

A major breakthrough in making these composite systems viable candidates for turbine blade application has been the successful development of a monolayer tape fabrication process shown in Fig. 19. Two techniques, one using powder cloth, the other alloy foils, are shown. It is envisioned that the latter will be more efficient for volume production and that turbine blade fabrication costs should approach those for current turbine engine titanium fan b1ades (64).

Major problem areas associated with the application of $\mathbf{W}$ fiber reinforced superalloys to turbine blades are fiber-matrix interaction (interdiffusional effects reduce wire strength) during fabrication and service exposure, and resistance to thermal and mechanical fatigue caused by turbine operational modes. The former problem has been greatly reduced by development of the monolayer tape fabrication process and by making appropriate adjustments to the matrix compositions. It now appears that the fibermatrix interaction factor should not be a deterrent to composite use in turbine blade application. The thermal fatigue problem stems from the large thermal mismatch between the superalloy matrix and the $W$ fibcrs. Only limited thermal fatigue data have been obtained to date but the most recent results obtained at NASA-Lewis and by other investigators suggest that this problem also is much nearer the solution stage. Fig. 20 shows some encouraging results for a $\mathrm{W}-1 \mathrm{Th} \mathrm{O}_{2} / \mathrm{FeCrA1Y}$ specimen subjected to 1000 cycles from room temperature to $1200^{\circ} \mathrm{C}$ (22000F) by direct-resistance-heating in a Nava1 Air Systems Command program conducted at TRW. No matrix or fiber cracking occurrea. However, considerable research. remains to be done before $W$ fiber reinforced superalloys can be used as turbine blades. 
Ceramics. - I'he ultimate in potential use temperature capability for turbine blade application resides in ceramic materials. As shown in Fig. 12, use temperatures on the order of 1200 to $1370^{\circ} \mathrm{C}$ (2200 to $2500 \mathrm{oF}$ ) can be expected. In addition to the potentially low cost of ceramics (about $1 / 10$ that of superalloys", their low density (about $1 / 3$ that of superalloys) together with their high strength-to-density ratios, make ceramics particularly desirable for rotating turbine blades where the primary stresses result from centrifugal forces. However, it is not reasonable to expect the characteristics of essentially no ductility and very low inpact resistance to be circumvented to the extent necessary to permit the use of ceramics as aircraft engine turbine blades much hefore the last decade of this century. There is a much greater likelihood that ceramic turbine blades will see service in ground power installations or automobiles considerably before this.

Although it is not feasible to achieve ductile ceramics, considerable effort is being expended to improve their impact resistance. Modest, although not consistently obtainable, improvements in impact strength have been obtained to date. Figure 21 shows the increases in both room temperature and $1315^{\circ} \mathrm{C}(24000 \mathrm{~F})$ impact strength achieved with $\mathrm{Si}_{3} \mathrm{~N}_{4}$ by various investigators. Increasing the purity of $\mathcal{X}$-phase $\mathrm{Si}_{3} \mathrm{~N}_{4}$ powders (65), application of a lithium aluminum silicate layer $(66)$, and carburization to create a compressive layer (67) have each provided an increase in impact strength. The last mentioned approach resulted in one $\mathrm{J}$ (10 in $1 \mathrm{~b}$ ) impact strength, a factor of ten increase over as-received $\mathrm{Si}_{3} \mathrm{~N}_{4}$. More impressive improvements in impact strength of $\mathrm{Si}_{3} \mathrm{~N}_{4}$ have resulted $(68,69,70)$ from reinforcing hot pressed $\mathrm{Si}_{3} \mathrm{~N}_{4}$ with $25 \mathrm{v} / \mathrm{o}$ Ta wire of 25 mil diameter. Drawbacks to this approach are the more than doubled density of the $\mathrm{Si}_{3} \mathrm{~N}_{4}-\mathrm{Ta}$ product over the monolithic $\mathrm{Si}_{3} \mathrm{~N}_{4}$ body $(6.55 \mathrm{~g} / \mathrm{cc}$ vs. $3.2 \mathrm{~g} / \mathrm{cc})$ and the possibility of catastrophic oxidation of any exposed $\mathrm{Ta}$ when the product is placed in service. Further improvements in impact resistance, particularly as regards reproducibility are anticipated, although much higher values of impact strength are not likely to be achieved.

In order to use ceramics for turbine blades, the designer must tailor his design philosophy to effectively deal with materials of essentially no ductility. Very early work by the authors $(71,72)$ recognized the need to accommodate the lack of ductility of ceramics by designs that employed cushioning interfaces between blades and disk and generous radii on the blade roots. Figure 22 illustrates some early attempts that were partially successful(72). The interface materials acted to further distribute the stress in the root attachments. Porous or screen material interfaces were especially beneficial. Interestingly, as was the case in the early NACA work, recent investigations $(73,74)$ have shown that the use of ductile inlerlayer materials such as platinum are highly desirable. These serve to distribute the stresses and to prevent chemical reaction between the ceramic blades and metal disks. Utilizing these methods, full-scale (4" span) blades were operated 20 years ago for as 1 ong as 240 hours at continuous fulI engine power without root failures. This was accomplished at a time when these engines were qualified for military service with a 150 hour test. The brittle airruils could not withstand the impact of typical foreign objects, however.

The early attempts to use ceramics and cermets as turbine blades were handicapped by relatively weak materials, rather immature ceramic processing procedures and very crude stress analysis techniques. Fortunately, designers today have far superior materials ( $\mathrm{SiC}$ and $\mathrm{Si}_{3} \mathrm{~N}_{4}$ ) to work with as well as design proccdurcs bascd on fracture mechanics and 3D finite-element stress analyses made possible by use of computers. The 3D finite-element stress analysis permits determination of local principal stresses throughout the component so that the designer can pin-point critical stress conditions which may result from stress concentrations. 
Fracturc mcchanics can be uscd to detcrminc the crack growth characteristics of the materials under design loads. Since the strength of ceramic materials is determined by initial flaw size and distribution, and since essentially no ductility is available to arrest crack growth, the careful application of fracture mechanics to ceramics is even more important than in the design of highly stressed metallic systems. The ceramic materials must be characterized by determining the sustained load subcritical crack growth and cyclic load crack growth. Fortunately, a good basis for this work has been established by the Nationa1 Bureau of Standards, and others $(75,76,77)$ working with glass, $\mathrm{Al}_{2} \mathrm{O}_{3}, \mathrm{SiC}$, and $\mathrm{Si}_{3} \mathrm{~N}_{4}$. However, it must be noted that for the ceramic data obtained to date, direct quantitative comparisons with $\mathrm{K}_{\mathrm{Ic}}$ values for metals can be misleading because of differences in the fracture toughness specimen sizes involved. Thus, relatively large specimens (inches in thickness) are used for metals whereas the specimen thickness of the ceramic specimens has typically been on the order of $30 \mathrm{mils}$. A rough indication of the relative fracture toughness of these materials is that a heat treated stee 1 has 30 to 50 times the fracture toughness of hot pressed $\mathrm{Si}_{3} \mathrm{~N}_{1}$.

Despite the difficulties and limitations however, the tools available to the designer today make designing around the ceramic ductility problem appreciably more possible than in the past. Nevertheless, the challenge is to learn how to effectively utilize these materials. Their extreme brittleness makes them far more sensitive to internal flaws inherent in their manufacture and to surface flaws resulting from accidental damage than has been true for any materials used heretofore in critical high stress applications such as blades.

\section{Environmental Protection}

Al1 of the metallic systems discussed for turbine stator vanes and blades require surface protection in order to realize their high use temperature potential for long service times. The turbine combustion gas poses problems of oxidation and hot corrosion which range in severity depending upon the type of fuel used and the atmospheric environment, In addition, turbine cyclic operational modes cause thermal fatigue cracking and protection against early failures of this type is needed.

Oxidation, hot corrosion, and thermal fatigue.- Significant advances have been made in the development of coatings for advanced superalloys in the past several years. The importance of this aspect of high temperature materials research cannot be over emphasized in view of the requirements for petroleum conservation which dictate the use of dirty fuels. Even greater effort is needed in this area to establish tolerance limits for materials and coatings and to provide improved coating protection for turbine blades and vancs so that such fuels can be used without lowering turbine operating temperatures. Figure 23 provides a summary of fue 1 costs as well as the impurity contents that contribute to hot corrosion and erosion in various grades of fuel. Associated with desirable reductions in fuel cost, are impurity content increases of several orders of magnitude which contribute to increased hot corrosion and erosion. Research on fuel additives is underway to reduce the harmful effects of impurities. However, the ultimate solution for longtime environmental protection lies in the development of suitable coating systems.

Figure 24 shows the effectiveness of some of the most advanced coating systems on two representative high strength nickel base alloys subjected to a cyclic operational mode in the LeRC Mach 1 burner facility. The cycles consisted alternately of 1 hour at $1090^{\circ} \mathrm{C}$ (2000\%) and 3 minutes at room temperature. Shown are cycles to first themal fatigue crack and cycles to first observed weight loss. The results are displayed from left to right in chronological order with the most recent development at the extreme 
right. Improvements over commcrcial aluminide coatings in cycles to first crack by factors of two to three and to first observed weight loss by a factor of almost eight have been obtained. The advanced coating systems displayed are described $(78,79,80)$ for the PVD COCrAIY, the aluminized NiCrAlSi and the Pt-Al systems, respectively. Figure 24 clearly shows a difference in coating performance for the two alloys. This emphasizes the necessity for tailoring the coating to the substrate. Such tailoring can most readily be achieved with the PVD process, since virtually any desired coating composition can be achieved simply by evaporation from a molten pool.

Figure 25 shows the hot corrosion behavior of these coating systems on the same two alloy substrates under cyclic operation in the Mach 1 burner. The cycle imposed consisted of 1 hour at $900^{\circ} \mathrm{C}\left(1650^{\circ} \mathrm{F}\right)$ and 3 minutes at room tcmperature. In this instance, 5 PAM salt was introduced into the combustion gas stream to simulate sulfidation conditions. Again, the same coating systems were not best for both alloy substrates. Also, the coating that provided the greatest oxidation protection was not necessarily the one that gave the best sulfidation protection for a particular substrate. It is apparent that the coating system must also be tailored to the substrate to achieve the most effective sulfidation protection.

Another promising approach (81) for increasing environmental protection is by compositiona 1 alterations to the substrate. Figure 26 shows how the cyclic oxidation resistance of a high $\boldsymbol{\gamma}^{\prime}$ content nickel base alloy was increased by sma 11 additions $(0.5 \mathrm{wt} . \%)$ of silicon. Negligible weight loss was observed after 300 cycles ( 1 hour at $1090^{\circ} \mathrm{C}$ (2000\%) followed by 3 minutes at room temperature) in the LeRC Mach 1 burner facility. Alloy performance was as good as with a commercial aluminide coating. Long time creep rupture properties were not degraded by the silicon addition when suitable heat treatments were applied. This approach should be exploited as a means of increasing the totality of environmental protection rather than as a substitute for coatings.

For the future coatings must be developed for long 1 ife protection for the advanced temperature ODS systems, the DS eutectics, and the $W$ fiber reinforced superalloy systems. AIthough the ODS NiCrAls do not require coatings for short time use (500 hours) they may require coating protection for long time service (thousands of hours). Significant progress is being made in this area. Thus, 1000 cycles ( $1 \mathrm{hr}$ at $1090^{\circ} \mathrm{C}$ (20000F), $3 \mathrm{~min}$. at R.T.) in the LeRC Mach 1 burner facility were run with PWA 267 (a PVD NiCrA1 coating) as we 11 as NASCOAT $70 \mathrm{M}$ (an aluminized PVD NiCrA1 coating) on a TD-NiCrAl substrate without significant weight loss. This represents a 25 to $30 \% 1$ ife improvement over uncoated TD-NiCrAl. In the area of advanced eutectics, excellent isothermal oxidation resistance has been achieved at $1090^{\circ} \mathrm{C}$ (2000\%) with the $\gamma / \gamma^{\prime}-\delta$ eutectic by means of a NiCraly plus Pt overlay coating (NAS3-18900). The coating also provides some improvement in resistance to thermal fatigue cracking. However, coating modifications are needed to increase coating ductility so as to further improve thermal fatigue resistance.

Because the overlay coating method is not dependent upon diffusion with the substrate, it affords the opportunity for applying a wide variety of coating compostions. Because of this versatility, the method has great appeal to the coating designer. However, the high cost of the PVD method (currently the most common method of applying overlay coatings) makes development of alternative low cost overlay coating processes of considerable importance. Finally, coating the increasingly complex internal cooling configurations of high temperature turbine blades and vanes poses an even more severe problem. Further work is needed to provide economically, as well as physical1y, viable techniques to meet this growing challenge. 
Thermal barriers.- Recent advances (82) have been made in providing insulating refractory oxide coatings on the order of $.25 \mathrm{~mm}$ (.010 in.) thick which provide effective thermal barriers on cooled turbine vanes and blades. The payoff consists of large reductions in both coolant flow and metal temperatures. For example, core engine turbine vanes coated with a $0.51 \mathrm{~mm}$ (.020 in) ceramic thermal barrier could have both an eightfold reduction in coolant flow and a $1100 \mathrm{C}(2000 \mathrm{~F})$ reduction in vane metal temperature compared to an uncooled vane (82). Figure 27 illustrates the concept and indicates some of the results obtained in cyclic burner facility tests and full-scale J-75 engine ground tests at NASA Lewis. The most favorable results have been obtained to date with $12 \% \mathrm{Y}_{2} \mathrm{O}_{3}$ and $3 \%$ MgO stabilized $\mathrm{ZrO}_{2}$ coatings $.25 \mathrm{~mm}$ (.010 in.) thick placed over a $0.1 \mathrm{~mm}$ (.004 in.) NiCrAl layer, plasma sprayed onto the blade surface. Figure 28 shows the tested fully bladed J-75 turbine whee 1 after 500 cycles from $1370^{\circ} \mathrm{C}$ (2500\%) to flame out. No cracking of the oxide was observed. The thermal barrier concept appears very promising, particularly for ground power applications, in which coating failures if they do occur are not so potentially dangerous. This approach may afford a way of extending the upper use temperature for turbine blades with current superalloy materials without the radical technology change required by substituting a new class of materials such as the DS eutectics.

\section{Future Efforts to Achieve Low}

\section{Strategic Material Content Alloys}

Potential strategic metal shortages are becoming a matter of increasing concern, particularly in view of the fact that much of our high temperature materials technology is dependent upon the extensive use of largely imported metals. Thus far, both government (DOD, AF, NRC, and to a lesser extent NASA) as well as the technical societies (ASM, AISI) have conducted surveyo and set up workshops to study this problem. For turbine applications, potentially the most serious problem resides with the use of chromium (a key constituent of both ferroalloys and superalloys) since we have no domestic reserves. The greatest known deposits are in Rhodesia (83). Extensive importa from there could pose political problems. The other major source is the USSR (83). Stainless and heat resisting steels make up $66 \%$, alloy steels $20 \%$, and superalloys $4 \%$ of the nation's metallurgical use of $\mathrm{Cr}$ ferroalloys $(84,85)$. An attempt is made in Fig. 29 (taken from a preliminary NASA study) to indicate the savings in $\mathrm{Cr}$ possible by means of various substitutional procedures or specification changes in ferroalloys containing $\mathrm{Cr}$. On $1 \mathrm{y}$ the most potential1y viable alternatives were considered. Although the materials considered in the figure have hot been discussed in this paper, they are used extensively in large ground base turbine power plants as casing and structural members. It is therefore appropriate to consider the overall effects of possible a1ternatives to their use. Figure 29 shows that the percentage and tonnage of Cr saved ranges from $5 \%$ ( 8300 Tons) by slightly modifying the 304 stainless steel specification, to $80 \%$ ( 94,600 Tons) by substituting low carbon s.tee 1 for 304 and using a 304 cladding. It is not possible to total the savings shown to arrive at a yearly savings figure, since some of the alternatives are mutually exclusive. Nevertheless, significant savings are obvious $1 y$ possiblc and such substitutional approaches as are suggested warrant further investigation in view of the potential seriousness of this problem.

\section{Summary}

Significant payoffs in turbine engine performance can be achieved by providing advanced materials for intermediate and high temperature components such as the disks, combustors, stator vanes, and turbine blades. Before such payoffs can be realized in engine service, formidable problems must be overcome in bringing materials capability to the level needed. These are, of course, the challenges faced by the materials technologist. 
For disks prealloyed powder superalloys are expected to afford both increased strength as well as reduced fabrication cost. For low stressed, high temperature components such as combustors and stator vanes, ODS alloys have a $90^{\circ} \mathrm{C}\left(160^{\circ} \mathrm{F}\right)$ higher use temperature potential than conventional sheet materials. Ceramics afford the highest use temperature potential, on the order of $1400^{\circ} \mathrm{C}\left(2600^{\circ} \mathrm{F}\right)$, of all materials for stator vanes with $\mathrm{SiC}$ and $\mathrm{Si}_{3} \mathrm{~N}_{4}$ being the most promising. For high stressed, high temperature components, such as the turbine blades, directional structures afford mafor improvements over the strongest conventional cast superalloys. The DS eutectic systems presently appear to offer as much as an $80^{\circ} \mathrm{C}\left(150^{\circ} \mathrm{F}\right)$ use temperature advantage. Although, the technology for tungsten fiber reinforced superalloys is not as advanced as that for DS eutectics, these composites afford potentially the highest use temperature capability of all the directional metallic systems with strengths as much as five times greater than current superalloys. The ultimate in use temperature capability for turbine component applications resides in ceramics with potential use temperatures as high as $1370 \mathrm{C}(2500 \mathrm{~F})$. To successfully apply ceramics to the high stressed turbine blades and disks, however, the designer will have to tailor his design philosophy to deal with these materials of essentially no ductility by utilizing fracture mechanics concepts and advanced 3D finite-element stress analysis techniques. Early applications wil1 probably need to operate at relatively low average stresses because of the low ductility.

Finally, the problem of providing environmental protection to turbine vanes and blades assumes an even greater importance than heretofore. The economic necessity for using dirty fuels containing greater quantities of impurities that contribute to hot corrosion and erosion demands that improved substrate/coating combinations be developed. This concept must be embodied in future advanced metallic system designs for high temperature turbine components.

\section{References}

1. Irwin Stambler: EPRI Gas Turbine Outlook. Gas Turbine World, November 1975, Vol. V, No. V, pp 19-22.

2. Energy Conversion Alternative Study (ECAS) - Final Report Phase I, Vols. I-XII, NASA CR-134941, Westinghouse Corporation, 1976.

3. Energy Conversion Alternative Study (ECAS) - Final Report Phase I, Vols. I-XII, NASA CR-134948, General Electric Company, 1976.

4. G. L. Brines: Studies for Determining the Optimum Propulsion System Characteristics for Use in a Long Range Transport Aircraft, NASA CR-120950, July 1972.

5. General Electric Company: Propulsion System Studies for an Advanced High Subsonic, Long Range Jet Commercial Transport Aircraft. NASA CR-121016, November 1972.

6. J. W. Bisset: Cost/Benefit Study of Advanced Materials Technologies for Aircraft Turbine Engines. NASA CR-134701, 1974.

7. E. W. Ross, R. P. Johnston, and R. E. Neitze1: Cost Benefit Study of Advanced Materials Technology for Aircraft Turbine Engines. NASA CR-134702, 1974.

8. J. B. Moore, J. Tequesta, and R. L Athey: Fabrication Method for the High Temperature Alloys. U. S. Patent 3,519,503. July 7, 1970.

9. J. C. Freche, W J. Waters, and R. I. Ashbrook: Method of Forming Superalloys. U. S. Patent 3,702,791, November 14, 1972. 
10. J. C. Freche, W. J. Waters, and R. L. Ashbrook: Method of Forming Articles of Manufacture from Superalloy Powders. U.S. Patent 3,775, 101. November $27,1973$.

11. Private communication with E. Kerzienik, General Electric Company, Cincinnati, Ohio

12. Private communication with Marvin M. Allen, FR\&DC, Pratt \& Whitney Corp.

13. Private communication with E. Rerzienik, General Electric Company, Cincinnati, Ohio

14. Private communication with W. B. Kent, Universal Cyclops, Bridgevilie, Pennsylvania.

15. Davis J. Evans: Evaluation of Powder Metallurgy Supera1loy Disk Materials. NASA CR-134865, 1975.

16. J. L. Bartos: Development of a Very High Strength Disk Alloy for 14000F Service. AFML-TR-74-187, AFML, 1974.

17. Marvin M. Allen, Bruce E. Woodings, John A. Miller: Advanced Wrought Nicke1-Base Alloy Turbine Disk Evaluation Program. PWA-FR-6035, Pratt \& Whitney Aircraft. (AFML-TR-73-271; AD-916496L), 1973.

18. R. V. Miner, Jr.: Effects of Carbon and Hafnium Concentration in Wrought Powder Metallurgy Superalloys Based on NASA IIB-11 Alloy. NASA TN D-8113, 1976.

19. P. T. Bizon and D. A. Spera: Comparative Thermal Fatigue Resistance of Twenty-Six Nicke1- and Cobalt-Base Alloys. NASA TN D-8071, October, 1975.

20. Hugh R. Gray: Turbine Materials and Life Prediction. Aeronautical Propulsion, NASA SP-381, May, 1975.

21. Peter G. Bailey: Oxide Dispersion Strengthened Alloys for Aircraft Turbine Engine Vanes. Materials on the Move, SAMPE National Technical Conference, Vo1. 6, October 1974.

22. J. W. Semmel, Jr.: Opportunities in Materials and Processes for Aircraft/Ship Propulsion Gas Turbines. Materials on the Move, SAMPE National Technical Conference, Vol. 6, October 1974.

23. Ward F. Simmons: Current and Future Materials Usage in Aircraft Gas Turbine Engines. Metals and Ceramics Information Center Report MCIC-73-14, June 1973.

24. L. J. Klingler, W. R. Weinberger, P. G. Bailey, and S. Baranow; Development of Dispersion Strengthened $\mathrm{Ni}-\mathrm{Cr}$ Alloy Sheet for Space Shuttle Vehicles. NASA CR-121164, December 1972.

25. John D. Whittenberger: Relation of Structure to Mechanical Properties of Thin, Thoria Dispersion Strengthened Ni-Cr Alloy Sheet. NASA TN D-7988, May 1975.

26. J. S. Benjamin: Dispersion Strengthened Superalloys by Mechanical Alloying. Metallurgical Transactions, Vol. 1, October 1970.

27. NASA Contract NAS3-19710: Low Cost Fabrication of ODS A1loy Vanes. General Electric Company. 
28. Daniel L. Deadmore, Carl E. Lowe11, and Gilbert J. Santoro: High Gas Velocity Oxidation and Hot Corrosion Testing of Oxide DispersionStrengthened Nicke1-Base Alloys. NASA TM X-71835, November 1975.

29. William A. Sanders and Hubert B. Probst: Evaluation of Oxidation ReGistant Nonmetallic Materials at $12040 \mathrm{C}$ (22000F) in a Mach 1 Burner. NASA TN D-6890, August, 1972.

30. William A. Sanders and Hubert B. Probst: Behavior of Ceramics at $1200^{\circ} \mathrm{C}$ in a Simulated Gas Turbine Environment. SAE Paper 740240, February 1974 .

31. C. G. Nessler: Gas Turbine Ceramic Vane Testing. SAE Paper 740235, February 1975 .

32. A. N. Holden, S. E. Mumford, and C. R. Booker, Jr.: Testing of Ceramic Stator Vanes to 25000F (13710C). ASME Paper 75-GT-103, March 1975.

33. Robert J. Beck: Evaluation of Ceramics for Sma11 Gas Turbine Engines. SAE Paper 740239, February 1974.

34. Arthur F. McLean: Ceramics in Smal1 Vehicular Gas Turbines. Ceramics for High Performance Applications, pp. 9-36, Brook Hi 11 Publishing Co.. 1974.

35. A. F. McLean, E. A. Fisher, and R. J. Bratton: Brittle Materials Design, High Temperature Gas Turbine. Ford Motor Co. (AMMRC-CTK-74-26; $A D-9206911,1974$.

36. W. J. Waters and J. C. Freche: A Nicke1-Base Alloy, NASA WAZ-16, with Potential for Gas Turbine Stator Vane Application, NASA TN D-7648, June, 1974 .

37. Thomas Vasilos: Improving the Toughness of Refractory Compounds. AVCO Corporation, NASA CR-134813, March, 1976

38. K. H. Jack and W. J. Wilson: Ceramics Based on the Si-AI-O-N and Related Systems. Nature Phys. Sci., Vo1. 238, No. 7, July 1972, pp. $28-29$.

39. NASA Contract NAS3-19698: Improved Ceramic Heat \$xchanger Materials. General Electric Valley Forge Space Center, Final report not yet issued.

40. NASA Contract NAS 3-19733: Improved Ceramic Heat Exchanger Materials. Owen-I1linois, Final report not yet issued.

41. A. F. McLean, E. A. Fisher, and D. E. Harrison: Brittle Materials Design, High Temperature Gas Turbine. Ford Motor Co. (AMMRC-CTR-72-3; $\mathrm{AD}-894052), 1972$.

42. A. F. McLean, E. A. Fisher, and R. J. Bratton: Brittle Materials Design, High Temperature Gas Turbine. Ford Motor Co. (AMMRG-CTR-72-19; $A D-905043), 1972$.

43. A. F. McLean, E. A. Fisher, and R. J. Bratton: Brittle Materials Design, High Temperature Gas Turbine. Ford Motpr Co. (AMMRC-CTR-73-9; $\mathrm{AD}-910446), 1973$.

44. A. F. Mclean, E A. Fisher, and R. J. Bratton: Brittle Materials Design, High Temperature Gas Turbine. Ford Motor Co. (AMMRC-CTR-73-32; $\mathrm{AD}-914451), 1973$. 
45. B. J. Piearcey and F. L. Ver Snyder: A New Development in Gas Turbine Materials. The Properties and Characteristics of PWA 664. Pratt and Whitney Aircraft Report No. 65-007, Apri1 21, 1975. 2nd Printing.

46. B. Piearcey and F. Ver Snyder: Monocrystaloys - A New Concept in Gas Turbine Materials. The Properties and Characteristics of PWA 1409. Pratt and Whitney Corporation. Report No. 66-007, February 2, 1966.

47. E. R. Thompson and F. D. Lemkey: Directionally Solidified Eutectic Superalloys, Metal Matrix Composites. Academic Press, 1973, Eds. L. Brontman and R. Krock.

48. C. A. Bruch: Eutectic Composite Turbine Blade Development.' General E1ectric Co., Contract F33615-73-C-5050.

49. R. L. Ashbrook: Directiona11y Solidified Composite Systems ui ler Evaluation. NASA TM X-71514, 1974.

50. K. D. Sheffler, R. H. Barkalow, and A. Yuen: Alloy and Structural Optimization of a Directionally Solidified Lamellar Eutectic Alloy. NAS 3-17811, PWA, Final report not yet issued.

51. L. F. Schulmeister, M. Cybulsky, and J. S. Erickson: Reduced Cost Processing for Eutectic Airfoils. PWA-IR-868-4, F33615-74-C-5018, On-going contract.

52. F. M. Dunlevey and J. F. Wallace: The Effect of Thermal Cycling on the Structure and Properties of a Co,Cr,Ni-TaC Directionally Solidified Eutectic Composite. NASA CR-121249 and Met. Trans., 5, June 1974, pp. $1351-1356$.

53. M. Ge11: Therma1 Stability of Directionally Solidified Composites . Specialists Meeting on Directionally Solidified In-Situ Composites, E, R. Thompson and P. R. Sahm, eds., AGARD-CP-156, 1974, Pp. 117-124.

54. Y. G. Kim: Structure and Thermal Cycling Stability of a Hafnium Monocarbide Reinforced Directionally Solidified Cobalt-Base Eutectic Alloy. NASA TM X-71751 and Proc. Conf. on In-Situ Composites II, 1975 (in press).

55. H. Bibring: Mechanical Behavior of Unidirectionally Solidified Composites. Proc. of Conf. on In-Situ Composites I, NMAB 308-II, pp. $1-69,1973$.

56. T. K. Glasgow: An Oxide dispersion Strengthened Ni-W-Al Alloy with Superior High Temperature Strength. Proceedings of Third International Conference on Superalloys. Seven Springs, Pennsylvania, Sept. 12-15, 1976.

57. R. L. Cairns, L. R. Curwick, and J. S. Benjamin: Grain Growth in Dispersion Strengthened Superalloys by Moving Zone Heat Treatments. Meta1lurgica1 Trans. A, Vo1. 6A, January 1975, p. 179.

58. A. V. Dean: The Reinforcement of Nickel-Base Alloys with High Strength Tungsten Wires. Rept. R-206, Nat. Gas Turbine Estab., England, April 1965.

59. R. H. Baskey: Fiber Reinforcement of Nonmetallic Composites. ASDTDR 63-619, July 1963.

60. D. W. Petrasek, R. A. Signorcl1i, and J. W. Weeton: Refractory Meta1 Fiber-Nicke1 Base Alloy Composites for Use at High Temperatures. NASA TN D-4787, 1968. 
61. D. W. Petrasek and R. A. Signorel1i: Preliminary Evaluation of Tungsten Alloy Fiber-Nickel Base Alloy Composites for Turbojet Engine Applications. NASA TN D-5575, 1970.

62. I. Ahmed, J. M. Bananno, K. E. Loomis, and W. J. Hefferman: Meta 1 Matrix Composites for High Temperature Applications. Rep. WVT-7155 (AD 734304), Watervilet Arsenal, October 1971.

63. R. A. Signorelli: Review of Status and Potential of Tungsten Wire/ Superalloy Composites for Advanced Gas Turbine Engine Blades. NASA TM X-2599, 1972.

64. R. A. Signore11i: Metal Matrix for Aircraft Propulsion Systems. NASA TM X-71685, 1975.

65. W. H. Rhodes and R. M. Cannon: High Temperature Compounds for Turbine Vanes. NASA CR-120966, September 1972.

66. H. P. Kirchner and J. Seretsky: Improving Impact Resistance of Ceramic Materials by Energy Absorbing Surface Layers. NASA CR-134644, August 1974.

67. H. P. Kirchner: Strengthening of Oxidation Resistant Materials for Gas Turbine Applications. NASA CR-134661, November 1974.

68. J. J. Bremnan and M. A. Decrescente: Fiber Reinforced Ceramic Matrix Composites. Contract N000-19-72-C0377, UARL Rpt. M911294-4, Jan, 15, 1973.

69. J. J. Brennan: Development of Fiber Reinforced Ceramic Matrix Composites. Contract N62269-73-C-0268. UARL Rpt. N911647-4, Apri1, 1974.

70. J. J. Brennan: Development of Fiber Reinforced Ceramic Matrix Composites. Contract N62269-74-C-0359, UARL Rpt. R911848-4, February 1975.

71. J. C. Freche: Further Investigation of Gas Turbine with NBS Body $4811 \mathrm{C}$ Ceramic Rotor Blades. NACA RM-49LO7, 1949.

72. G. C. Deutsch, A. J. Meyer, and G. M. Ault: A Review of the Development of Cermets. Report 185, Advisory Group for Aeronautical Research and Development, NATO, March-April 1958.

73. B. Walker: Ceramic B lade-Superalloy Disk Attachment. FRDC Pratt \& Whitney Corp., Contract N00019-74-C-0484, July through December 1975.

74. G. Calvert: Ceramic Blade-Metal Disk Attachment. FRDC Pratt \& Whitney Corp., NASA Contract NAS3-19715.

75. A. G. Evans, L. R. Russe11, and D. W. Richerson: Slow Crack Growth in Ceramic Materials at Elevated Temperatures. Metallurgical Trans. A, Vol. 6A, April 1.975.

76. R. W. Davidge, J. R. McLaren, and G. Tappin: Strength-ProbabilityTime (SPT) Relationships in Ceramics. Journal of Materials Science, 1973.

77. Fracture Mechanics of Ceramics. Edited by R. C. Bradt, D.P.H. Hasselman, and F. F. Lange. Plenum Press 1973.

78. F. P. Talboom, R. C. Elem and L. W. Wilson: Evalue"ion of Advanced Superalloy Protection Systems. NASA.CR-72813, December 1970.

79. M. A. Gedwi11, and S. J. Grisaffe: Oxidation Resistant Claddings for Supera1loys. Metals Eng. Quarterly, Vo1. 12, PP. 55-61, May 1972. 
80. Anon: A Platinum Barrier Layer for Nickel Alloys. Protection of Gas Turbine Blades, Platinum Metals Review, Vo1. 16, July 1972, p. 87, Johns on Mathey and Co. Ltd.

81. R. V. Miner, Jr. and C. E. Lowe11: Effects of Silicon Additions on Oxidation and Mechanical Behavior of the Nickel-Base Superalloy B-1900. NASA TN D-7989, June 1975.

82. C. H. Liebert and F. S. Slepka: Potential Use of a Ceramic Coating as a Thermal Insulation on Cooled Turbine Hardware. NASA TM X-3352, February 1976.

83. Commodity Data Summaries. Bureau of Mines. U. S. Dept. of. the Interior, 1975.

84. Metal Statistics, 1975. Amcrican Metal Market.

85. Summary Report on Air Force Chromium Workshop. Wright-Patterson Air Force Base, Ohio, May 1975.

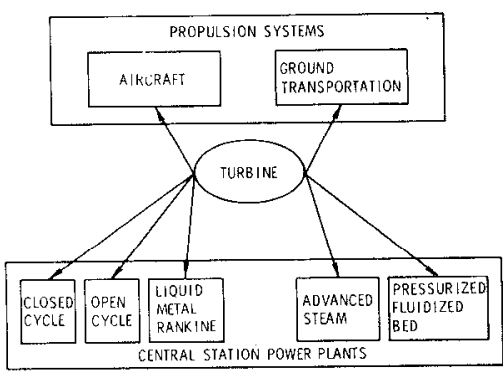

Fiqure 1. - Turbines are key to variety of powerplants.

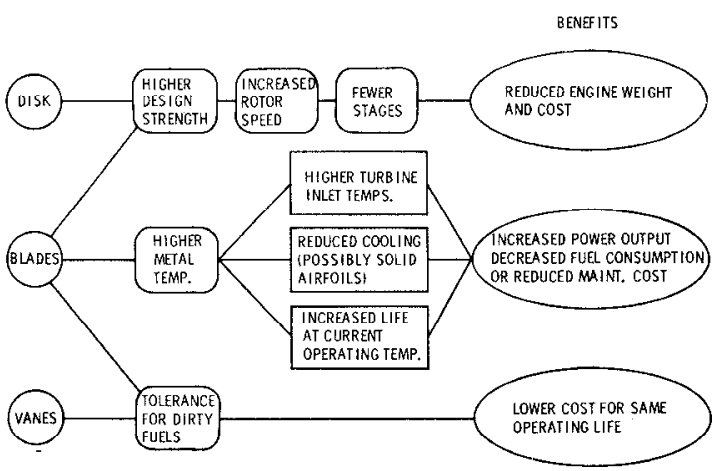

Figure 2 - Turbine engine payofits from advanced materia ls.

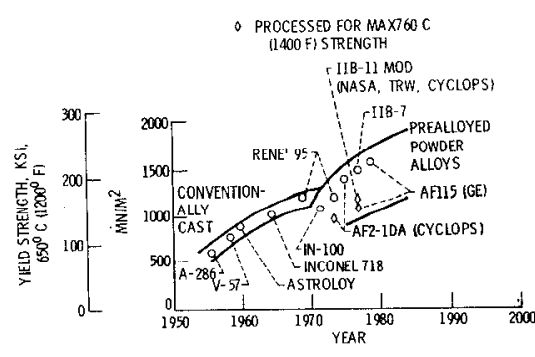

Figure 3. - increased yield strength projected for prealloyed powder alloys.

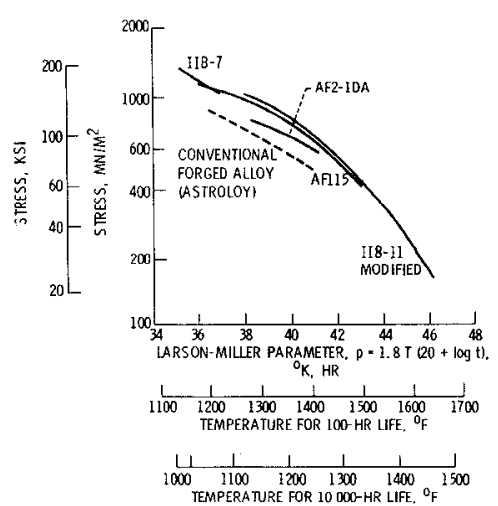

Figure 4. - Prealloyed powder alloys superior to currentiy used cunventiural cast and furged altoy in stress to rupture. 


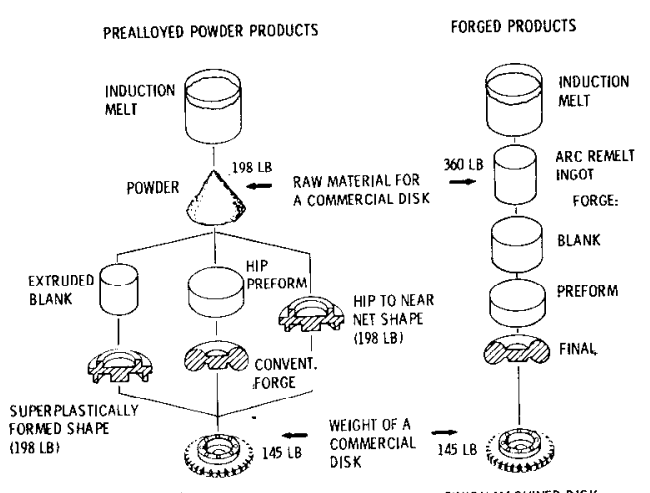

FINISH MACHINED DISK

FINISH MACHINED DISK

Figure 5. - Prealloyed powder process sermits reduced costs in disk fabrication compared to conventional forging process.

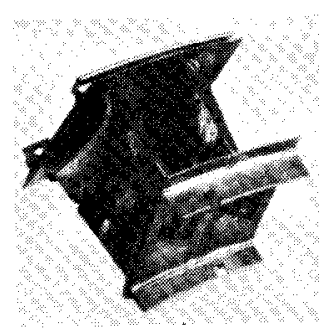

COOLED MAR-M 509 VANE

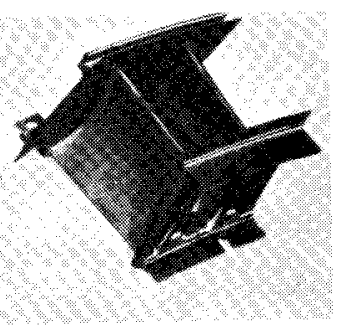

UNCOOLED TDNICr VANE
Figure 7. - Superiority of ODS vanes compared to conventionally cast under overtemperature conditions.

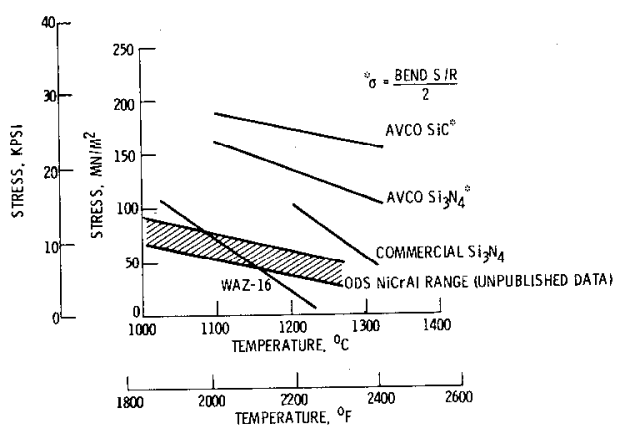

Figure 9. - Ceramics show significant stress rupture strength increase over metallic vane materials.

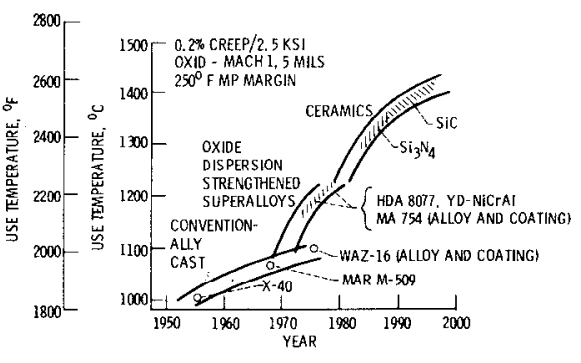

Figure 6. - Increased use temperature projected for ODS superalloys and ceranics for high temperature low stress applications.

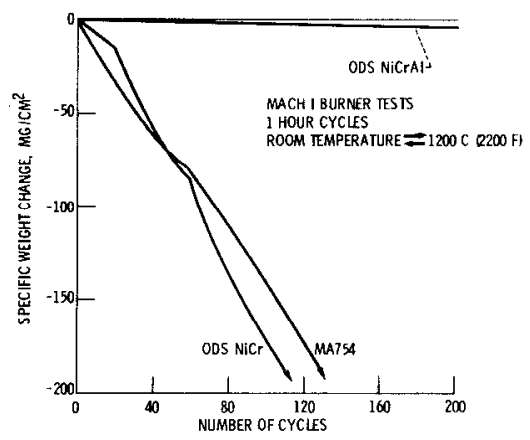

Figure 8. - Changing to NiCrAl base affords substantial improvement in cyclic oxidation resistance of ODS alloys.

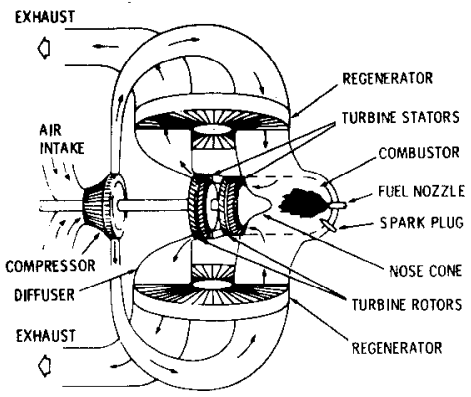

REGENERATOR MATERIAL - LITHIUM ALUMINUM SILICATE

WHY HIGHER CYCLE OPERATING TEMPERATURE REGENERATOR? LOWER COST THAN METAL HONEYCOMB

PROBLEM: $\begin{aligned} & \text { CORROSIVE ATTACK BY Na AND } \mathrm{H}_{2} \mathrm{SO}_{4} \\ & \text { LEADS TO INSTABLITIES UPON } \\ & \text { THERMAL CYCLING }\end{aligned}$ Fiqure 10. - Regenerative gas turbine for automotive use. Key problem reramic regenerator.

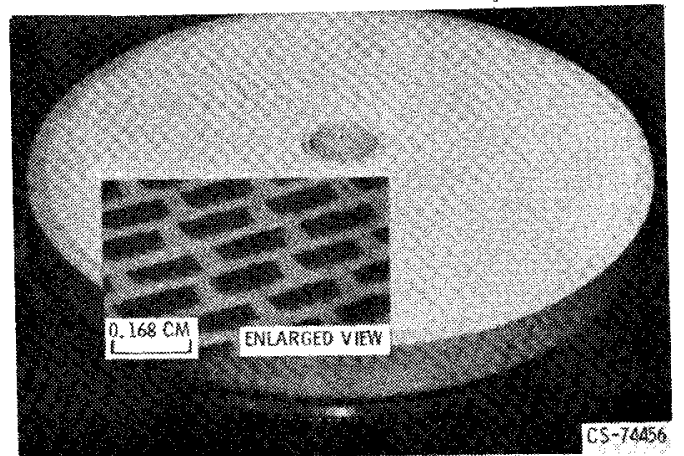

Figure 11. - Typical ceramic regenerator disk. 


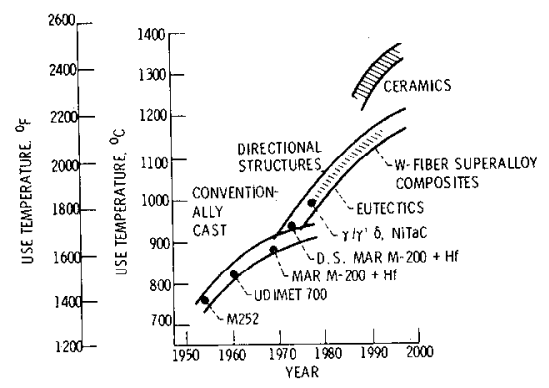

Figure 12. - Increased use temperature projected for directional struc$30 \times 5 i, 5000$ hours.

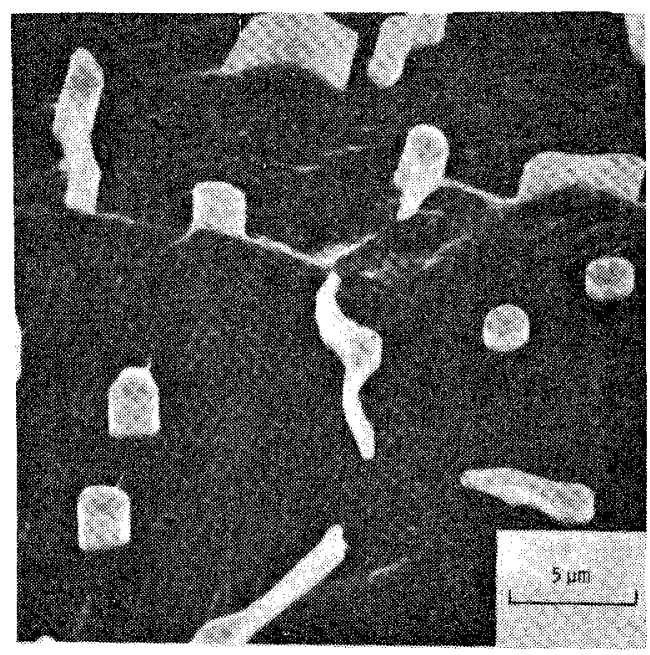

ROD HFC; HAFCO

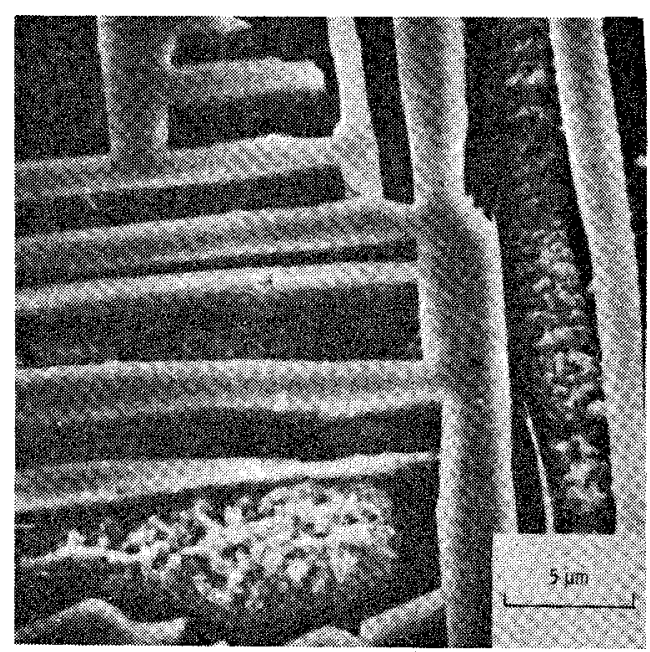

LAMELLAR Ni ${ }_{3} \mathrm{Cb} ; \gamma / \gamma^{\prime}-\delta$

Figure 14. - I wo types of DS eutectics

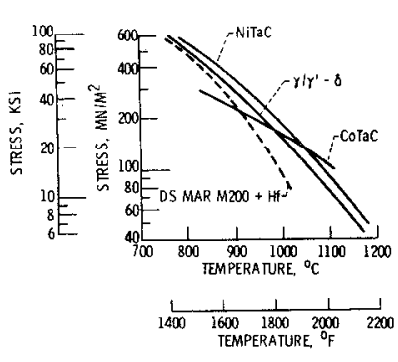

Figure 13. - Directionally solidified eutectic alloys

tor blade apolication show significant advantage

over conventional superalloy in $\mathbf{1 0 0 0}$ hour stress

rupture.
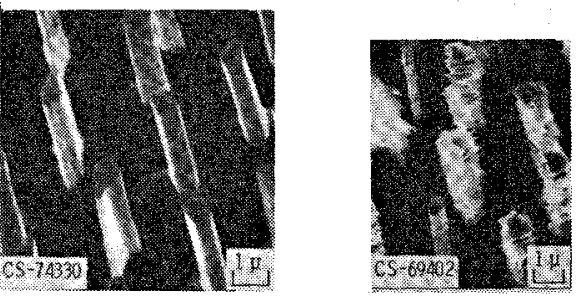

DIRECTIONALLY SOLIDIFIED COTaC $1 \mathrm{CO}-20$ TO $25 \mathrm{Ni}-15 \mathrm{Cr}-12 \mathrm{~T} a-0.8 \mathrm{C})$

(a) AS-CAST.

(b) 2000 CYCLES, $425^{\circ} \mathrm{C}$ $1797^{\circ} \mathrm{F} \div 1100^{\circ} \mathrm{C}\left(2012^{\circ} \mathrm{F}\right)$
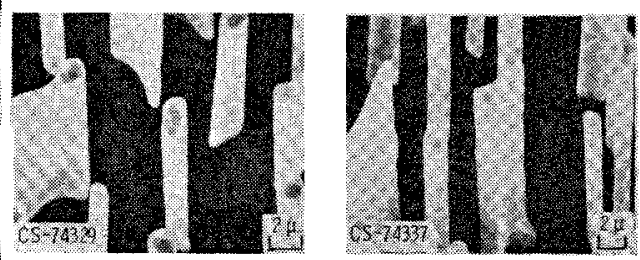

DIRECIIONALLY SOLIOIFIED HafCo (Co- $\chi$ TO $25 \mathrm{Ni}-15 \mathrm{Cr}-10.5 \mathrm{Hf}-0.7 \mathrm{C})$.

(c) AS-CAST.

(d) $\left.2500 \mathrm{CYCLES}, 425^{\circ} \mathrm{C} 1797^{\circ} \mathrm{F}\right)$
$1100^{\circ} \mathrm{C}\left(2012^{\circ} \mathrm{F}\right)$

Figure 15. - Compositional change may be needed to insure thermal stability of directionally solidified eutectics.

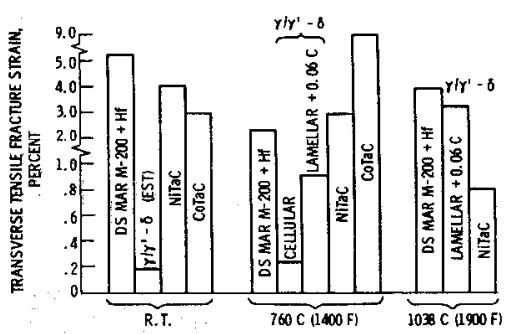

Figure 16, - Transwer se ductllity problem with some DS eutectics. 


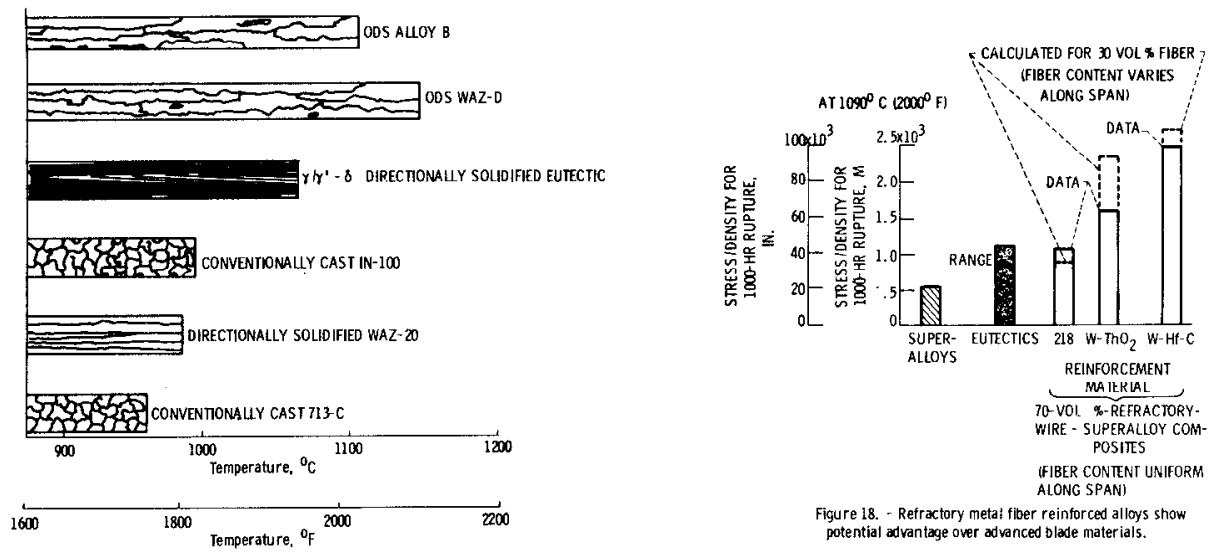

Figure 17. - Oxide dispers ion strengthening plus garma prime strengthening provides large use temperature increases oyer conventionally cast and directionally solidified alloys; test conditionsi $103 \mathrm{MN} / \mathrm{M}^{2}$ a $15 \mathrm{ksi}$ ), 1000 hour life.

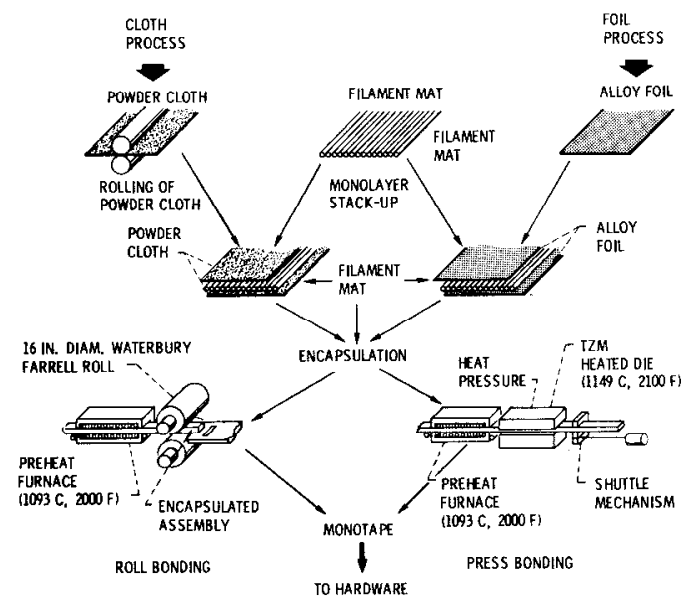

Figure 19. - Flow diagram of diffusion bonding techniques for the manufacture of tungsten fiber - Ni alloy matrix monotapes.
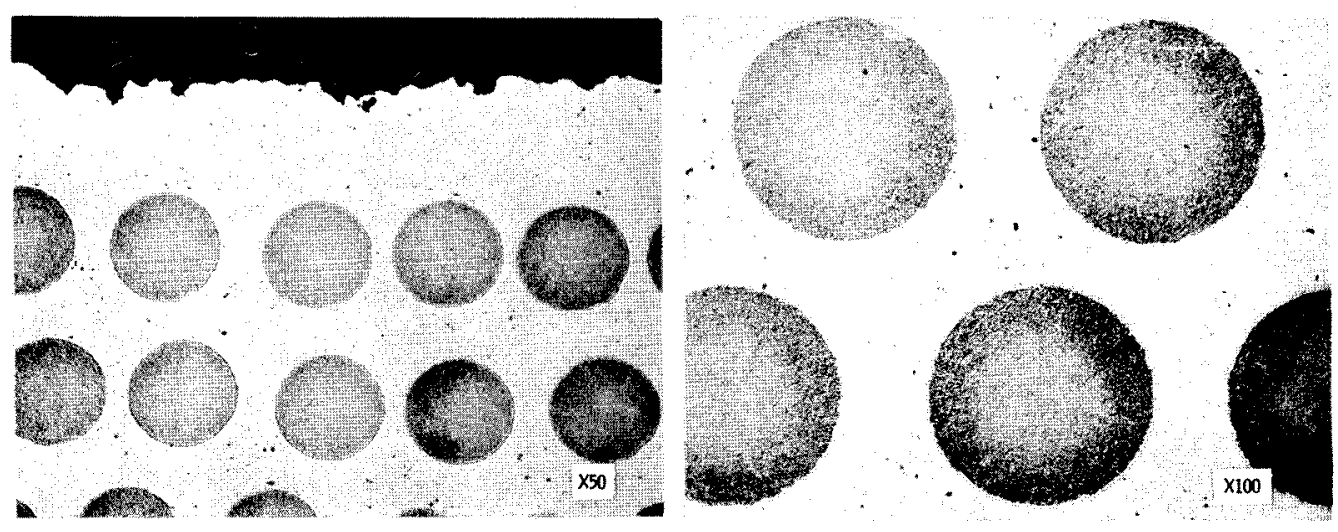

1000 CYCLES $30-1200^{\circ} \mathrm{C}\left(85-2200^{\circ} \mathrm{F}\right.$.

Figure 0 . - Thermally cycled tungsten wire reinforced superalloy composite promises acceptable thermal fatigue resistance. (W-1 ThO $\left.0_{2} / \mathrm{FeCrAYY}\right)$ Naval Air Systems Command program at TRW. 


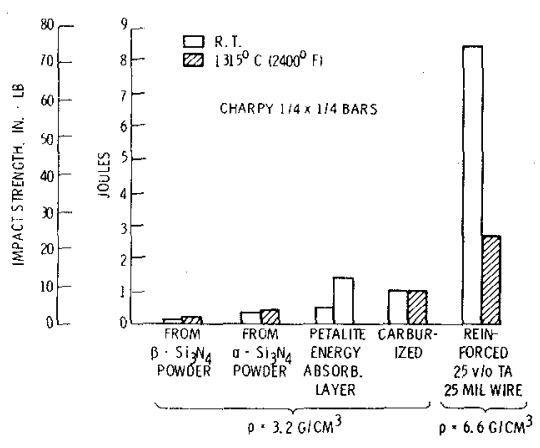

Figure 21. - Impact strength improvements in $\mathrm{Si}_{3} \mathrm{~N}_{4}$ ceramic.

\begin{tabular}{|c|c|c|}
\hline TYTE ROOT & $\begin{array}{c}\text { Maximum LIIC, } \\
\mathrm{HR}\end{array}$ & TESF RESULT'S \\
\hline & 3 & BENDING IN ROOT \\
\hline & 2] & BENDING IN ROOI \\
\hline & 68 & BENDING IN ROOT \\
\hline & 59 & BENDING IN ROOT \\
\hline & $\begin{array}{c}\mathrm{a}_{242} \\
\text { (ALSO } 108 \text { CYCIES) }\end{array}$ & $\begin{array}{l}\text { COMPRESSION IN ROOT } \\
\text { CAUSED PIN TO LOOSEN. } \\
\text { NO ROOT FALLURES }\end{array}$ \\
\hline 43 & $a_{150}$ & $\begin{array}{l}\text { AIRFOIL INO ROOT } \\
\text { FAILURESI }\end{array}$ \\
\hline
\end{tabular}

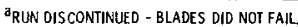

Figure 22 - Early efforts to handle problem of low ductility of ceramic

\begin{tabular}{|c|c|c|c|c|c|c|c|c|}
\hline FUEL TYPE & $\begin{array}{c}\text { IMPUR } \\
\text { TO } \\
V^{2} \\
\text { (PPM) }\end{array}$ & $\begin{array}{l}\text { ITIES C } \\
\text { HOI CC } \\
\text { Na+K, } \\
\text { (PPM) }\end{array}$ & $\begin{array}{l}\text { NTRIB } \\
\text { RROSI } \\
\text { Pb, } \\
\text { (PPM) }\end{array}$ & ${ }_{(x)}$ & $\begin{array}{l}\text { IMPUR } \\
\text { ASH } \\
\text { IPPM! }\end{array}$ & $\begin{array}{l}\text { RITIES CONTRIBUT ING } \\
\text { TO EROSION } \\
\text { FILTERABLE DIRT } \\
\%\end{array}$ & $\begin{array}{r}\cos \\
\$ 10^{6}\end{array}$ & BTU \\
\hline KEROSENE & 0.1 & 0.1 & -- & 0.1 z & $\cdots$ & .002 & 2.80 & 1 \\
\hline NO. $1 G^{\text {rak }}$ & 20 & 5.0 & 5.0 & $\begin{aligned} 0.5 & \text { 옹 } \\
& \text { 훙 }\end{aligned}$ & 100 & $.002 \frac{z}{\frac{z}{n}}$ & & $\begin{array}{r}5 \\
0 \\
0\end{array}$ \\
\hline $\mathrm{H}-\mathrm{COAL} \mathrm{L}^{(\mathrm{b})}$ & 20 & 5.0 & --- & 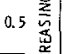 & 2000 & 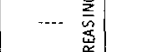 & 2.25 & 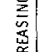 \\
\hline $\begin{array}{l}\text { SELECTED } \\
\text { CRUDE OIL }\end{array}$ & 500 & 10.0 & 5.0 & 276 & 300 & .2 & 200 & 1 \\
\hline
\end{tabular}

${ }_{\text {ASTM 2880-71 }}$

REF. ECAS TASK EIIN PRINTI - COAL DERIVED LIQUUID FUEL

Figure 23. - Dirty gas turbine liquid fuels cost less than kerosene but increase hot corrosion and erosion.

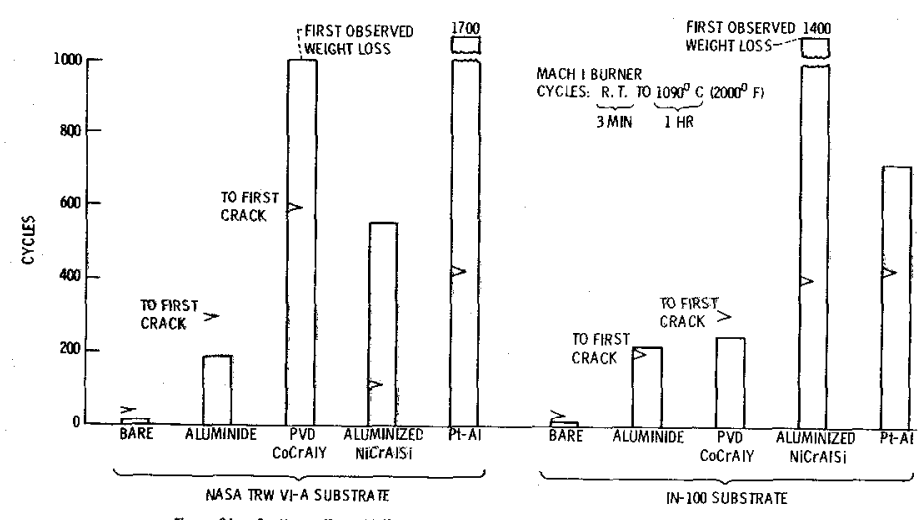

Flgure 24. - Caatings offer axitation and thermal fatigue protection but must be tailored to substrato. 

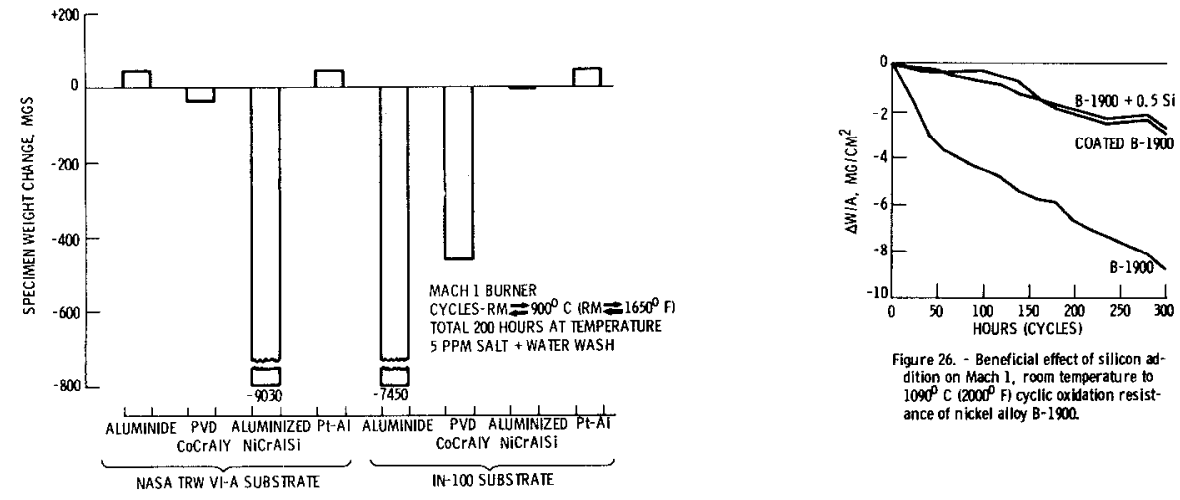

Figure 26. - Beneficial effect of silicon 3 dition on Mach $\mathrm{l}$, room temper ature to $1090^{\circ} \mathrm{C}$ (2000) Heyclic oxidation resist ance of nickel alloy B-1900.

Figure 25. - Coatings afford hot corrosion protection but must be tailored to substrate.

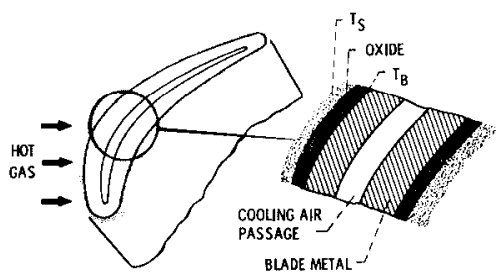

M 0.3RIG - 182, 1+R CYCLES

$\mathrm{T}_{\mathrm{S}}=1426^{\circ} \mathrm{C}\left(2600^{\circ} \mathrm{F}\right) \mathrm{T}_{\mathrm{B}}=98^{\circ} \mathrm{C}\left(1700^{\circ} \mathrm{F}\right) \quad \triangle \mathrm{T}=480^{\circ} \mathrm{C}\left(900^{\circ} \mathrm{F}\right)$

$J 75$ ENGINE TEST - 500, 1-MIN (AT MAX TEMPY CYCLES $T_{S}=1060^{\circ} \mathrm{C}\left(1950^{\circ} \mathrm{F}\right) \quad T_{B}=900^{\circ} \mathrm{C}\left(1650^{\circ} \mathrm{F}\right) \quad \Delta \mathrm{T}=150^{\circ} \mathrm{C}\left(300^{\circ} \mathrm{F}\right)$

Figure 27 . - Thermal barrier concept - coatings insulate turtine blades.

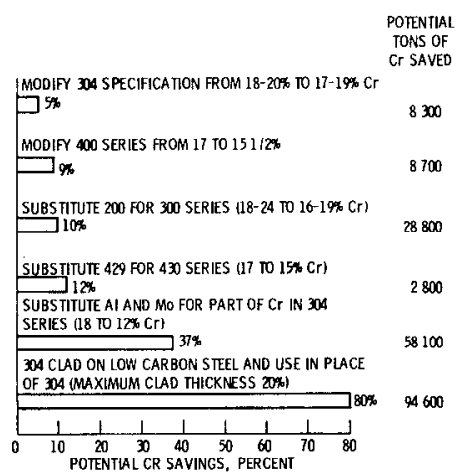

Figure 29. - Savings in chromium possible by alloy modification and substitution.

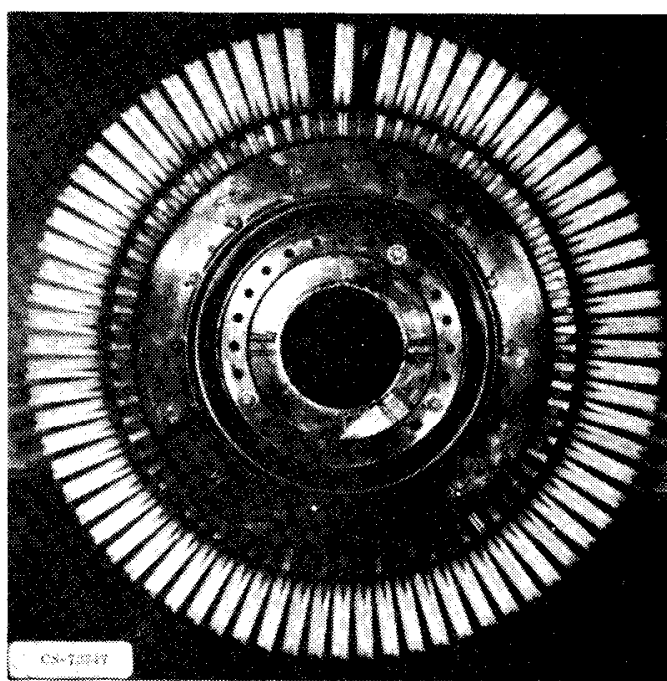

Figure 28. - Ceramic coated turbine blades. I 75 first stage rotor after 500 cycles operation, $1370^{\circ} \mathrm{C}\left(2500^{\circ} \mathrm{F}\right)$ turbine inlet to flame out. 